\section{Sowing dates and densities on physiological potential of seeds of white oat cultivars}

\author{
José Henrique Bizzarri Bazzo ${ }^{1 *}$ (D) , Klever Márcio Antunes Arruda² ${ }^{(D)}$, Inês \\ Cristina de Batista Fonseca ${ }^{1}\left(\mathbb{D}\right.$, Claudemir Zucareli ${ }^{1}$
}

ABSTRACT: The aim of this study was to evaluate the physiological potential of seeds of white oat cultivars grown at different sowing dates and densities. Two independent experiments were conducted with two different sowing dates in a randomized block experimental design in a $4 \times 2$ factorial arrangement, with four replications. The treatments consisted of four sowing densities $\left(180,240,300\right.$, and 360 viable seed. $\mathrm{m}^{-2}$ ) and two cultivars (IPR Afrodite and IPR Artemis). The following evaluations were made: thousand seed weight, germination percentage, first germination count, seedling length, seedling dry matter, emergence speed index, and seedling emergence in sand. Joint analysis of variance was carried out on the data regarding sowing dates separately for the cultivars. The mean values for sowing dates were compared by the F test; and polynomial regression analysis up to the second degree at $5 \%$ probability was conducted on the densities. The seeds produced by the plants grown from the first sowing date had better vigor than those produced by plants from the later sowing date. The increase in sowing density reduces the weight and vigor of the seeds produced by plants from the second sowing date. For the IPR Afrodite and IPR Artemis cultivars, the use of 180 seed. $\mathrm{m}^{-2}$ in the first growing period allows production of seeds with greater physiological potential.

Index terms: plant population, Avena sativa L., growing environments, vigor, germination.

\section{Épocas e densidades de semeadura no potencial fisiológico de sementes de cultivares de aveia branca}

RESUMO: Objetivou-se avaliar o potencial fisiológico de sementes de cultivares de aveia branca cultivadas em diferentes épocas e densidades de semeadura. Dois experimentos independentes foram conduzidos em duas épocas de semeadura, utilizando-se o delineamento experimental de blocos casualizados em esquema fatorial $4 \times 2$, com quatro repetições. Os tratamentos constaram de quatro densidades de semeadura $\left(180,240,300\right.$ e 360 sementes viáveis. $\left.\mathrm{m}^{-2}\right)$ e duas cultivares (IPR Afrodite e IPR Artemis). Foram avaliados: massa de mil sementes, geminação, primeira contagem da germinação, comprimento e massa seca de plântula, índice de velocidade de emergência e emergência de plântulas em areia. Os dados foram submetidos à análise de variância conjunta para épocas de semeadura, separadamente para as cultivares. As médias de épocas foram comparadas pelo teste $\mathrm{F}$ e as de densidades submetidas à análise de regressão polinomial até segundo grau, a $5 \%$ de probabilidade. As sementes produzidas na primeira época de semeadura apresentam melhor vigor. $\mathrm{O}$ aumento da densidade de semeadura reduz a massa e o vigor das sementes produzidas na segunda época de cultivo. Para as cultivares IPR Afrodite e IPR Artemis, a utilização de 180 sementes. $\mathrm{m}^{-2}$, na primeira época de semeadura, possibilita a produção de sementes de melhor potencial fisiológico.

Termos para indexação: população de plantas, Avena sativa L., ambientes de cultivo, vigor, germinação.
Journal of Seed Science, v.42, e202042023, 2020

http://dx.doi.org/10.1590/ 2317-1545v42232390
${ }^{*}$ Corresponding author
E-mail: josebazzo@uel.br

Received: 12/19/2019

Accepted: 03/02/2020

${ }^{1}$ Departamento de Agronomia, Universidade Estadual de Londrina (UEL), Caixa Postal 6001, 86057-970 Londrina, PR, Brazil.

${ }^{2}$ Instituto Agronômico do Paraná, 86047-902 - Londrina, PR, Brazil. 


\section{INTRODUCTION}

Seed quality is one of the main factors that affect establishment and performance of crops, and it is related to the sum of the genetic, physical, physiological, and health aspects that affect the capacity of seeds to give rise to highyielding plants (Marcos-Filho, 2015). Physiological potential is related to the ability of the seed in performing its vital functions, bringing together information regarding seed germination and vigor (Carvalho and Nakagawa, 2012).

The quantity and quality of seeds produced can be maximized by sowing at periods of the year that favor the growth, development, and yield performance of the plant. This management practice is characterized by changing the relationships among the meteorological elements available to the crop during its cycle (Silva et al., 2011; TafernaberriJúnior et al., 2012; Bornhofen et al., 2015). This plant growing strategy combines the different phenological stages of the crop with the environmental conditions most favorable to the plant, which has a positive impact on the production and distribution of assimilates and, consequently, on seed yield and quality (Toledo et al., 2009).

Understanding the relationship between time elements of the crop environments and the yield performance of cultivars is essential for producing seeds of superior quality at satisfactory yield levels (Gomes et al., 2012; Silva et al., 2014). According to Caron et al. (2017), the characterization of phenological modifications that occur in plants as a result of contrasting sowing dates is important for defining the adoption of crop practices that assist in taking better advantage of environmental conditions and in maximizing the yield of better quality seeds from each sowing/growing period.

One of the important management techniques that can be combined with the temporal aspect of crop seasons, aiming to increase seed yield and physiological performance, is sowing density (Carvalho and Nakagawa, 2012; Abati et al., 2017), since it modifies inter- and intraspecific competition for resources from the growth medium and, consequently, the number and composition of the seeds (Almeida and Mundstock, 2001).

Variations in sowing densities in the oat crop modify the number of tillers (Almeida and Mundstock, 2001) and bring about significant modifications in yield components (Schuch et al., 2000a). In addition, sowing density leads to morphophysiological changes in plants (Zagonel et al., 2002), which can affect their growth and development and, consequently, seed yield and quality.

Costa et al. (2013) report that cultivars can differ in capacity to produce tillers, in their cycle, and in seed yield potential. Thus, the effort of establishing appropriate sowing density should also take the genotypes and the sowing/ growing period into consideration, to reduce competition and promote an increase in seed yield and seed quality from the cultivars (Freitas et al., 2010; Tavares et al., 2014).

Thus, the sowing densities associated with the genotype and with the sowing/growing period can have an effect on yield components, such as number of tillers, number of panicles, and the number of seeds per area, with a direct effect on plant potential for seed filling and, consequently, the weight and number of seeds per panicle. Therefore, appropriate management can result in larger and heavier seeds that may have a greater amount of reserves, which would affect their physiological performance.

Thus, the aim of this study was to evaluate the physiological potential of seeds of white oat cultivars grown at different sowing dates and densities.

\section{MATERIALS AND METHODS}

Two independent experiments, with two different sowing dates (May 5 and June 24), were carried out in Londrina, $\mathrm{PR}$, at the Experimental Station of the Instituto Agronômico do Paraná (IAPAR) in a Latossolo Vermelho eutroférrico at $23^{\circ} 23^{\prime} \mathrm{S}$ and $51^{\circ} 11^{\prime} \mathrm{W}$, at an altitude of $610 \mathrm{~m}$. Climate in the region, according to the Köppen classification is type Cfa, described as humid subtropical with hot summers, few frosts, and a tendency for concentration of rains in the summer months, though without a defined dry season. Rainfall and temperature data were obtained from records of the IAPAR meteorological stations (Figure 1). 


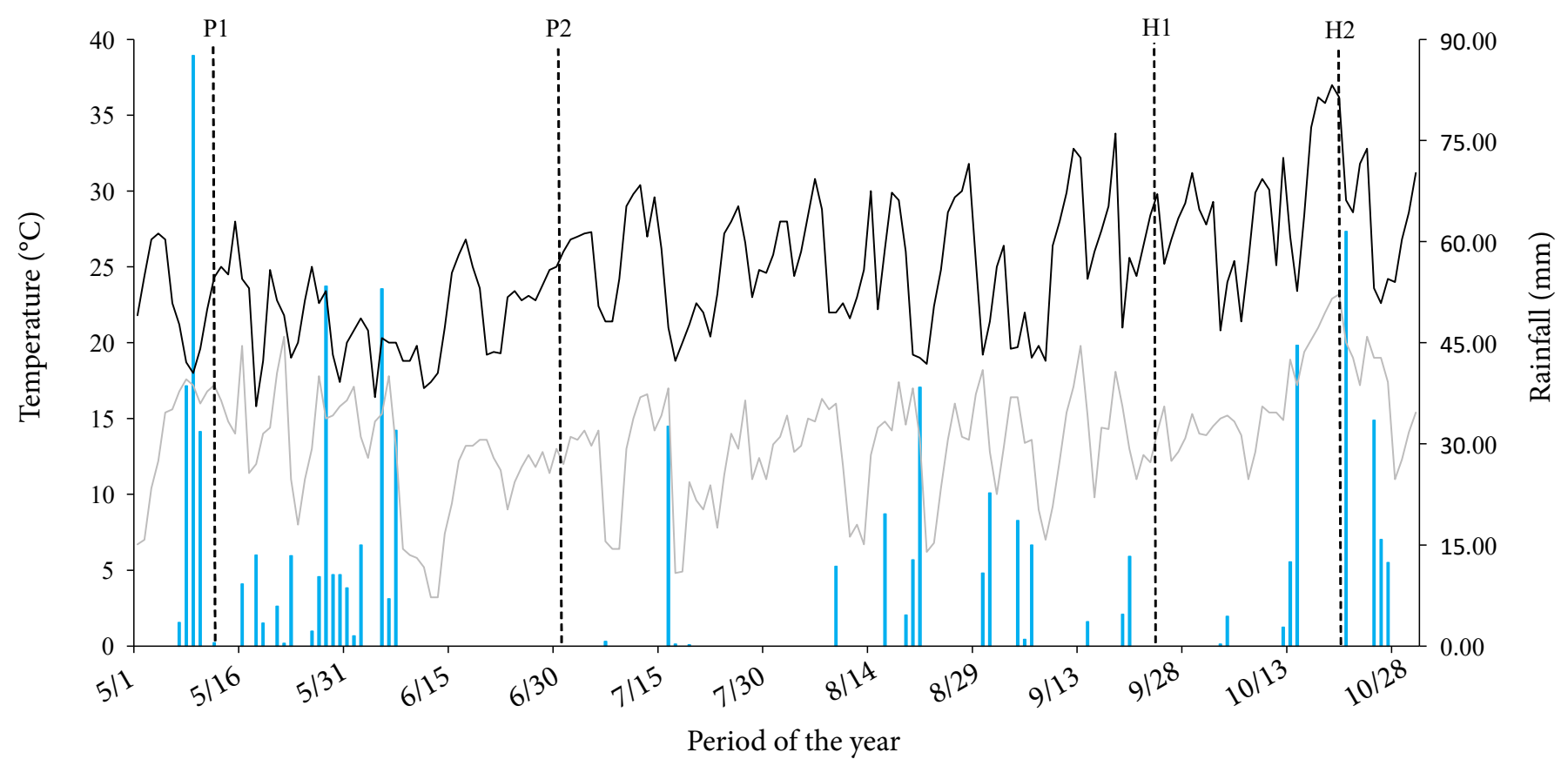

P1: seedling emergence period 1 (May, 13); P2: seedling emergence period 2 (July, 1); H1: harvest period 1 (September, 23); H2: harvest period 2 (October, 21).

Figure 1. Daily data of maximum and minimum temperatures (lines) and rainfall (bars) for the period of conducting the experiments.

The chemical characteristics of the soil at the depths of $0-10 \mathrm{~cm}$ and $10-20 \mathrm{~cm}$, determined before setting up the experiment, were as follows: $0-10 \mathrm{~cm}-\mathrm{pH}\left(\mathrm{CaCl}_{2}\right) 4.80,5.76 \mathrm{cmol}_{\mathrm{c}} \cdot \mathrm{dm}^{-3} \mathrm{H}+\mathrm{Al}^{3+}, 4.42 \mathrm{cmol} \cdot \mathrm{cm}^{-3} \mathrm{Ca}^{2+}, 1.56 \mathrm{cmol}_{\mathrm{c}} \cdot \mathrm{dm}^{-3}$ $\mathrm{Mg}^{2+}, 0.35 \mathrm{cmol} \cdot \mathrm{dm}^{-3} \mathrm{~K}^{+}, 36.3 \mathrm{mg} . \mathrm{dm}^{-3} \mathrm{P}$, and $19.09 \mathrm{~g} . \mathrm{dm}^{-3}$ organic matter; and for $10-20 \mathrm{~cm}-\mathrm{pH}\left(\mathrm{CaCl}_{2}\right) 4.90,5.76$ $\mathrm{cmol}_{\mathrm{c}} \cdot \mathrm{dm}^{-3} \mathrm{H}+\mathrm{Al}^{3+}, 4.57 \mathrm{cmol}_{\mathrm{c}} \cdot \mathrm{dm}^{-3} \mathrm{Ca}^{2+}, 1.52 \mathrm{cmol}_{\mathrm{c}} \cdot \mathrm{dm}^{-3} \mathrm{Mg}^{2+}, 0.27 \mathrm{cmol}_{\mathrm{c}} \cdot \mathrm{dm}^{-3} \mathrm{~K}^{+}, 15.1 \mathrm{mg} \cdot \mathrm{dm}^{-3} \mathrm{P}$, and $16.59 \mathrm{~g} \cdot \mathrm{dm}^{-3}$ organic matter.

The trials were conducted using the cultivars IPR Afrodite (medium cycle, moderate resistance to lodging, medium stature, released in 2012 by IAPAR) and IPR Artemis (medium cycle, moderate resistance to lodging, medium statute, released in 2016 by IAPAR). In both experiments, at the two sowing dates, a randomized block experimental design was used in a $4 \times 2$ factorial arrangement, with four replications. Treatments consisted of four sowing densities (180, 240, 300, and 360 viable seed. $\mathrm{m}^{-2}$ ) and two cultivars (IPR Afrodite and IPR Artemis). The plots were composed of six 5-meterlength rows at a spacing of $0.17 \mathrm{~m}$ between rows; and an area of $5.1 \mathrm{~m}^{2}$ was used for data collection.

The experiments were conducted under a conventional soil management system in an area previously planted to soybean. The chemical characteristics of the soil of the experimental area were the basis for calculation of base mineral fertilization in the planting furrow, constant for all the treatments, which was $20 \mathrm{~kg}$.ha-1 N, $60 \mathrm{~kg} \cdot \mathrm{ha}^{-1} \mathrm{P}_{2} \mathrm{O}_{5}$, and 20 kg.ha-1 $\mathrm{K}_{2} \mathrm{O}$, using $200 \mathrm{~kg}$.ha-1 of the formulation 10-30-10.

The plant health treatments for disease control and other crop treatments were carried out according to need and recommendations for the crop. Seeds were harvested upon reaching maturity for harvest, a stage characterized by hardening of the caryopsis, plants with a dry appearance, and seeds with moisture below $20 \%$. The following evaluations were carried out for determination of seed physiological potential:

Thousand seed weight: obtained through counting and weighing of eight replications of one hundred seeds of oats per plot. The mean of these values was multiplied by ten to obtain the value of thousand seed weight (Brasil, 2009).

Germination percentage: performed with eight replications of fifty seeds in Germitest ${ }^{\circ}$ paper towel moistened with distilled water in the amount of 2.5 times the weight of the substrate. The rolls of paper towel were kept in a seed 
germinator at a temperature of $20^{\circ} \mathrm{C}$. Evaluation consisted of two counts, at five (first count) and at ten (final count) days after setting up the test, and then calculating the percentage of normal seedlings (Brasil, 2009).

Seedling length: performed by sowing four replications of twenty seeds in the upper third of the sheet of Germitest ${ }^{\circ}$ paper, moistened with distilled water at the rate of 2.5 times the weight of the dry paper. The rolls of paper containing the seeds remained for five days in a seed germinator at a temperature of $20^{\circ} \mathrm{C}$, at which time the length of normal seedlings was evaluated using a millimeter ruler (Nakagawa, 1999). Results were expressed in centimeters per seedling.

Seedling dry matter: the normal seedlings, coming from the test of seedling length, were placed in paper bags and then in a forced air circulation laboratory oven regulated to a temperature of $80^{\circ} \mathrm{C}$ to constant weight (Nakagawa, 1999). Dry matter was evaluated and results were expressed in mg.seedling ${ }^{-1}$.

Seedling emergence in sand: performed in a greenhouse with four replications of fifty seeds per treatment, sown at a depth of $3 \mathrm{~cm}$. The sand used was previously washed and then placed in plastic trays. Moisture was maintained through irrigation according to need. Evaluation of the number of normal seedlings that emerged was performed on the fifteen day after sowing (Nakagawa, 1999).

Seedling emergence speed index: performed together with the seedling emergence in sand test through daily counts of the number of normal seedlings emerged, up to stabilization of emergence, according to the formula proposed by Maguire (1962).

The data were analyzed for normality and homogeneity of errors, and then joint analysis of variance was performed for sowing dates separately for the cultivars. The mean values from sowing dates were compared by the $F$ test, and the mean values of densities were analyzed through second order polynomial regression, at $5 \%$ probability.

\section{RESULTS AND DISCUSSION}

For the IPR Afrodite cultivar, there was an effect of interaction between the sowing date and sowing density factors for the thousand seed weight and seedling dry matter traits. For the variables first germination count, seedling length, and emergence speed index, an isolated effect of sowing date was found. Only the first germination count exhibited a significant isolated effect of sowing densities. No significant effect of sowing dates, densities, and interaction between the factors was found for the germination percentage and seedling emergence in sand variables.

For the IPR Artemis cultivar, a significant interaction was found between the sowing date and sowing density factors for the thousand seed weight, first germination count, seedling length, and seedling dry matter traits. An isolated effect of sowing/growing periods was found only for the emergence speed index. A significant effect of sowing dates, sowing densities, and interaction between the factors was not found for the germination percentage and seedling emergence in sand variables.

Rainfall during the cycle of plants grown from the first sowing date was $622.70 \mathrm{~mm}$, whereas in the second sowing date it was $336.80 \mathrm{~mm}$ (Figure 1). In the later growing period, the amount of rainfall was below the minimum required by the crop, with the period of most accentuated water restriction during the vegetative growth phase. However, for both sowing dates, the rainfall distribution was uneven, which may have altered the agronomic performance and, possibly, seed formation and physiological potential.

One thousand seed weight of the IPR Afrodite and IPR Artemis cultivars in the first sowing date (period 1) did not exhibit an effect of sowing density. In the second sowing date (period 2), this trait fit quadratic equations, with minimum values at 264 seed. $\mathrm{m}^{-2}$ for IPR Afrodite and 258 seed. $\mathrm{m}^{-2}$ for IPR Artemis (Figures 2A and 2B).

For both cultivars, at all sowing densities, period 1 resulted in production of seeds with greater weight. This can be explained by the better meteorological conditions (better rain distribution and milder temperatures) during the vegetative growth and development phase of the plants grown in this period (Figure 1), thus allowing them to accumulate a greater amount of dry matter, increasing seed weight.

Caron et al. (2017), working with two maize hybrids (Dekalb 240 and Dow AgroSciences 2A106) and six sowing 
dates $(9 / 15,9 / 30,10 / 15,10 / 30,11 / 16$, and 12/3) in Frederico Westphalen, Brazil, also found that both cultivars had lower thousand seed weight when sown later. Similar results were found also for the rice crop, in which Venske et al. (2016) compared the effect of two sowing dates (10/18 and 11/9) on the yield components and seed yield of the cultivar IRGA 424 and found that thousand seed weight decreased in the second growing period.

In relation to sowing density, results similar to those found for thousand seed weight of the IPR Afrodite and IPR Artemis cultivars were obtained by Almeida et al. (2003), who worked with four oat cultivars (UFRGS 14, UFRGS 18, UPF 16, and UPF 17), five plant densities (50, 185, 320, 455, and 590 plant. $\mathrm{m}^{-2}$ ) and two crop years (1998 and 1999). They found that, in 1998, thousand seed weight of the cultivars UPF 17, UFRGS14, and UFRGS 18 did not exhibit a significant effect for plant density, and found that the same variable for the UPF 16 cultivar fit a quadratic equation with a minimum value of 390.90 plant. $\mathrm{m}^{-2}$. A study performed by Tavares et al. (2014), with the aim of evaluating the response of wheat genotypes (PF 014384, BRS Tangará, and BRS Pardela) grown at different sowing densities (150, 250, 350, and 450 viable seed. $\mathrm{m}^{-2}$ ) in Londrina, PR, and Ponta Grossa, PR, in two crop years in regard to yield components and seed yield, also exhibited results similar to those obtained in the present study for seed weight. In that study, the authors concluded that thousand seed weight was not affected by sowing densities in either location in the first year.
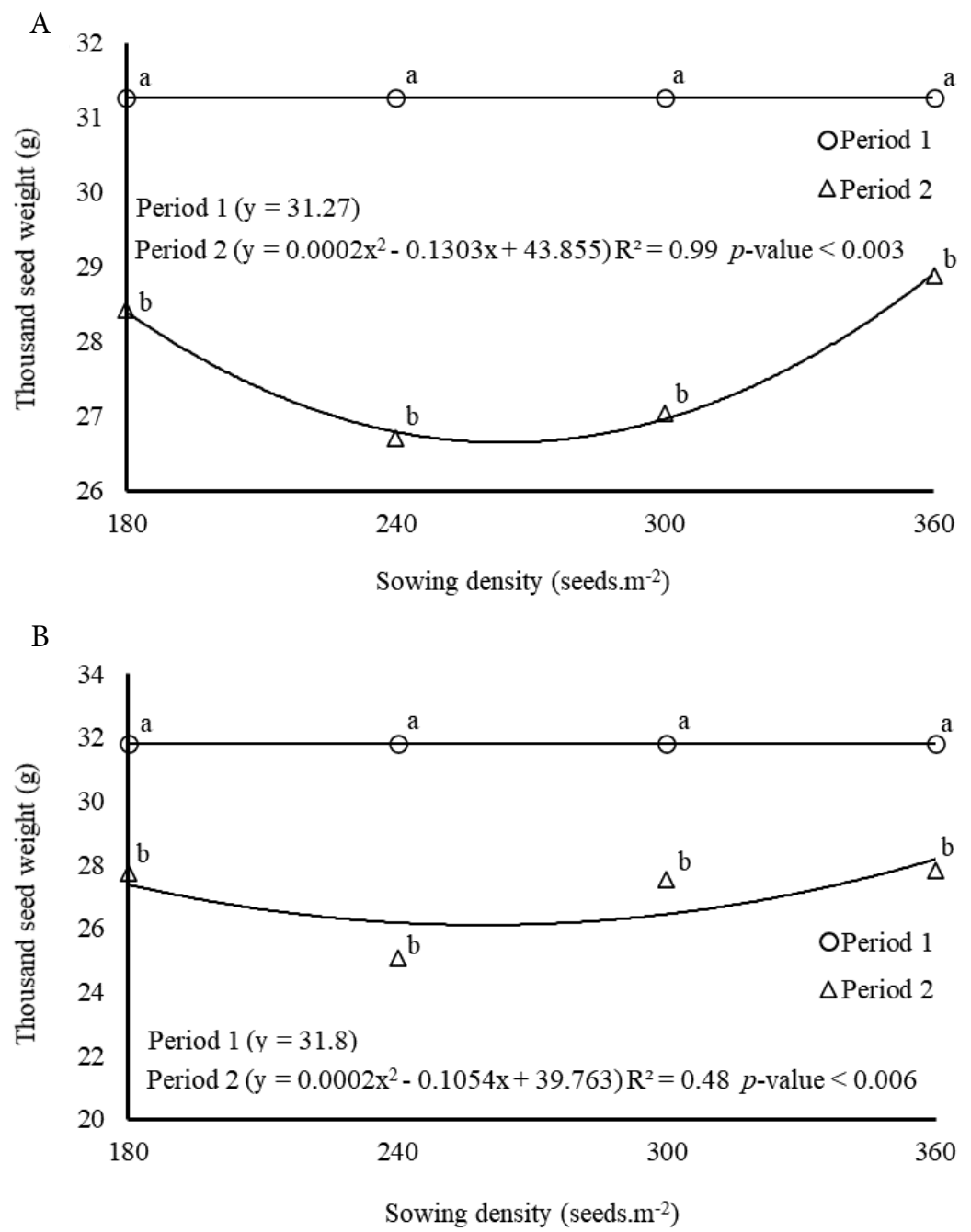

Figure 2. Thousand seed weight of seeds from the white oat cultivars IPR Afrodite (A) and IPR Artemis (B) grown under different sowing dates and sowing densities. 
In contrast, in Ponta Grossa and Londrina in the second year, they found that a quadratic equation fit thousand seed weight, as a result of the increase in the number of seeds per unit area.

Although seed germination of the IPR Afrodite and IPR Artemis cultivars did not exhibit an isolated effect or an effect of interaction among the factors analyzed, in this study, it nevertheless resulted in a percentage of normal seedlings above the standard established for sale of oat seeds by the Brazilian Ministry of Agriculture (Ministério da Agricultura, Pecuária e Abastecimento - MAPA) in all the treatments, a standard which requires minimum germination of $80 \%$.

Results for the IPR Afrodite cultivar showed that period 1 favored first germination count of seeds (Table 1), just as observed by Venske et al. (2015) who evaluated the effect of two sowing dates (10/18 and 11/19) on the physiological quality of rice seeds produced in Capão do Leão, Brazil, and also found that the percentage of normal seedlings in first germination count was higher in the first growing period.

In relation to sowing density, the first germination count of seeds of the IPR Afrodite cultivar, regardless of the sowing date, fit a quadratic equation with a minimum value of 279.78 seed. $\mathrm{m}^{-2}$ (Figure $3 \mathrm{~A}$ ). In this case, it is noteworthy that the amplitude of change in the number of normal seedlings found in the first germination count was low among the sowing densities.

For the IPR Artemis cultivar, the first germination count, of seed germination, in period 1, was not significantly altered by the increase in sowing density. However, in period 2, this trait fit a decreasing linear function in response to increase in seed. $\mathrm{m}^{2}$ (Figure 3B). At the density of 180 seed. $\mathrm{m}^{-2}$, there was no significant difference between period 1 and period 2. However, at the densities of 300 and 360 seed. $\mathrm{m}^{-2}$, the second plant growth period exhibited lower values for the trait evaluated, through the decreasing linear function. Different results were obtained in studies conducted by Salau et al. (2017) and Schuch et al. (2000b), who evaluated the effect of different populations of plants on the physiological potential of barley and black oat seeds, respectively. They found no effect from the increase in the number of plants per unit area on seed vigor expressed through the first germination count test.

Seedling length for the IPR Afrodite cultivar was greater for seeds coming from period 1 (Table 1). This result corroborates that found by Venske et al. (2015) who, working with rice growing, also found that sowing at a later date caused a reduction in seed quality, shown by lower performance of seeds in the seedling length test.

The IPR Artemis cultivar did not have a significantly different response to the increase in seed. $\mathrm{m}^{-2}$ in terms of the length of seedlings coming from its seeds produced in period 1 . However, for the seeds coming from period 2 , this trait fit a decreasing linear function as a response to an increase in seed. $\mathrm{m}^{-2}$ (Figure 4). At the density of 180 seed. $\mathrm{m}^{-2}$, there was no significant difference between period 1 and period 2 for the variable analyzed. However, for the other seed densities, period 1 led to production of seeds that produced seedlings of greater length.

Table 1. Mean values of first germination count (FGC), seedling length (SL), and emergence speed index (ESI) of the seeds from two oat cultivars grown under two different sowing dates (Period 1: May 5; Period 2: June 24).

\begin{tabular}{cccc}
\hline \multirow{2}{*}{ Sowing date/growing period } & \multicolumn{3}{c}{ IPR Afrodite } \\
\cline { 2 - 4 } & FGC (\%) & SL (cm) & ESI (\%) \\
\hline Period 1 & $99 \mathrm{~A}$ & $16.52 \mathrm{~A}$ & $10.44 \mathrm{~A}$ \\
Period 2 & $97 \mathrm{~B}$ & $15.18 \mathrm{~B}$ & 3.75 \\
\hline CV (\%) & 1.95 & 7.24 & \\
\hline \multirow{2}{*}{ Sowing date/growing period } & \multicolumn{3}{c}{ IPR Artemis } \\
\hline Period 1 & ESI (\%) \\
\hline Period 2 & $10.45 \mathrm{~A}$ & \\
\hline CV (\%) & & $9.87 \mathrm{~B}$ & \\
\hline
\end{tabular}

Mean values followed by the same letter in the column do not differ from each other by the $\mathrm{F}$ test $(p<0.05)$. 
Dry matter of seedlings coming from seeds of the IPR Afrodite cultivar produced in period 1 did not show a significant effect from sowing density. However, for seeds from period 2, this variable fit a quadratic equation with a minimum value of 284 seeds.m ${ }^{-2}$ (Figure 5A). The densities of 180 and 360 seed. $\mathrm{m}^{-2}$ did not lead to a significant difference between period 1 and period 2 for the variable in question. However, seeds from the densities of 240 and 300 seed. $\mathrm{m}^{2}$ in period 1 showed higher values for seedling dry matter.
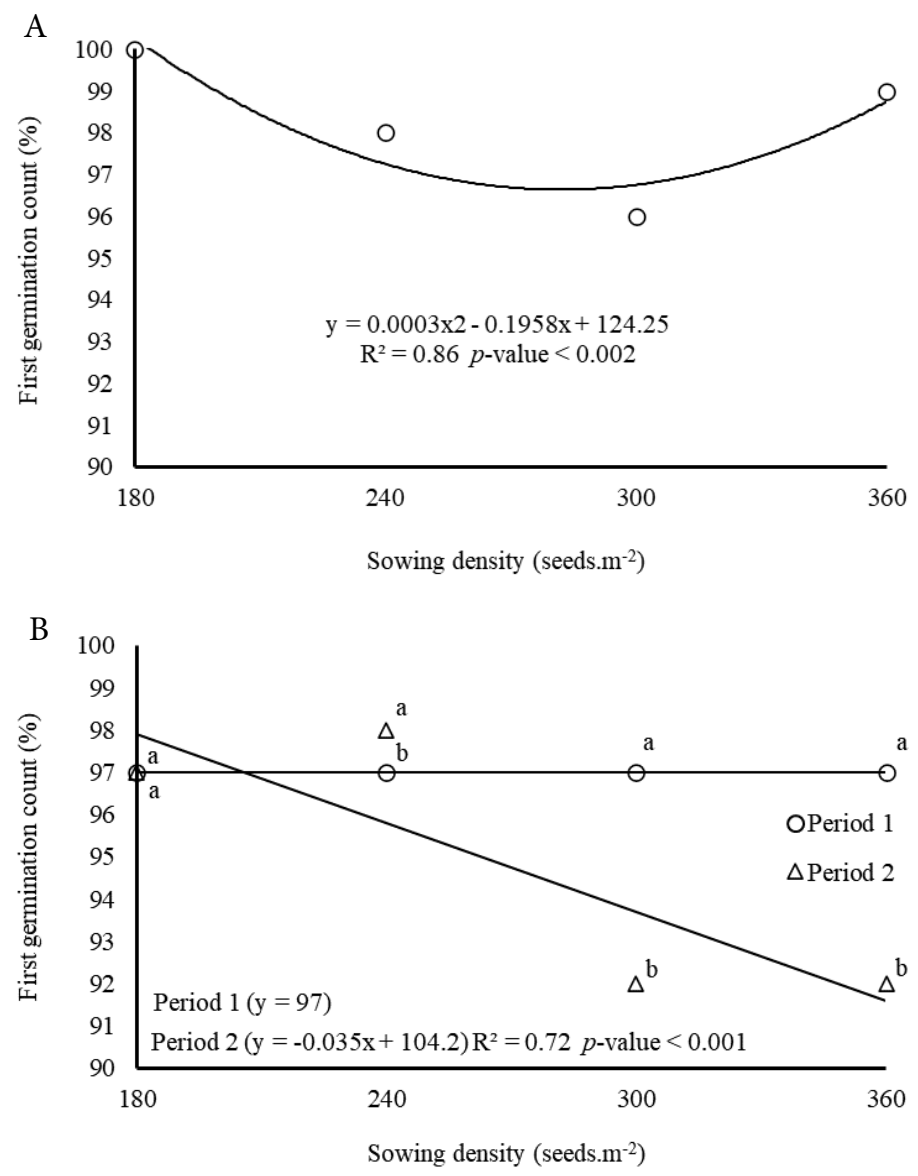

Figure 3. First germination count of seeds from the white oat cultivar IPR Afrodite (A) grown under different sowing densities, and IPR Artemis (B) grown under different sowing dates and sowing densities.

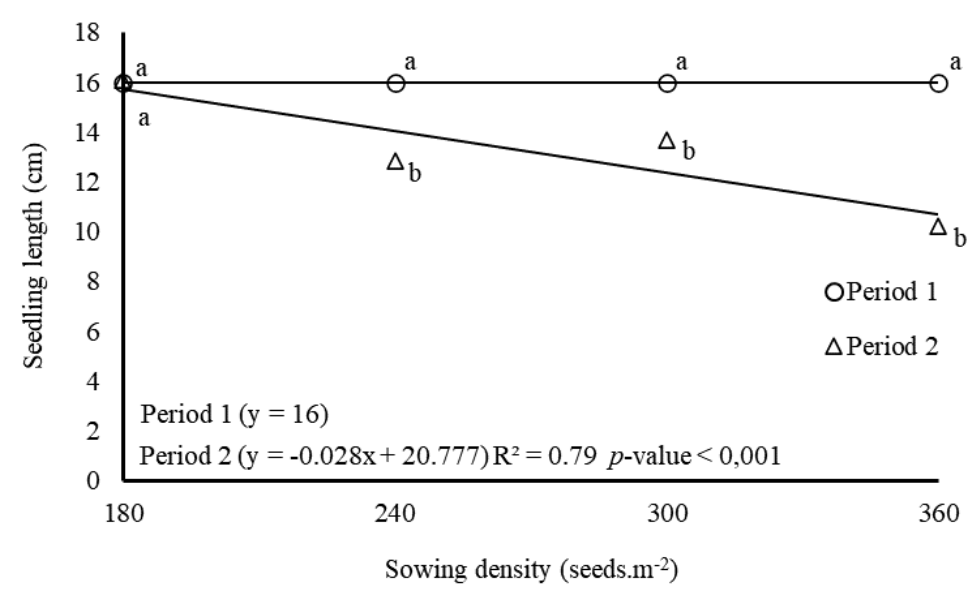

Figure 4. Length of seedlings from seeds from the white oat cultivar IPR Artemis grown under different sowing dates and sowing densities. 

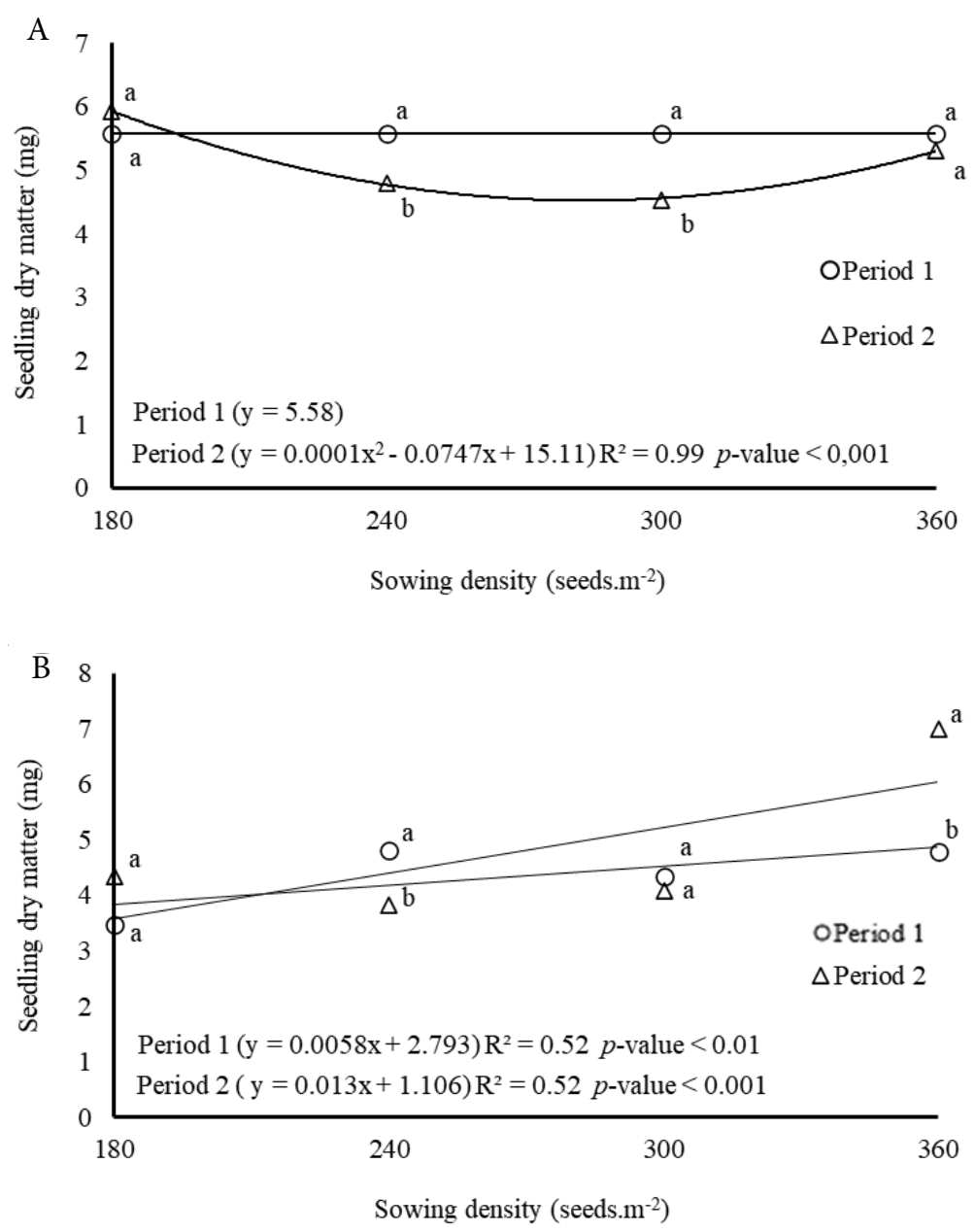

Figure 5. Dry matter of seedlings from seeds from the white oat cultivars IPR Afrodite (A) and IPR Artemis (B) grown under different sowing dates and sowing densities.

For the IPR Artemis cultivar, the dry matter of seedlings coming from seeds grown in period 1 and 2 fit increasing linear equations in response to the increase in sowing density (Figure 5B). The densities of 180 and $300 \mathrm{seed}^{-2} \mathrm{~m}^{-2}$ did not exhibit significant difference between period 1 and period 2 for the variable in question. However, the densities of 240 and 360 seed. $\mathrm{m}^{-2}$ in period 1 led to greater and lower oat seedling dry matter, respectively.

Results that contrast with those found in the present study regarding the effect of sowing dates on the results of seedling dry matter were obtained by Venske et al. (2015), who found that shoot and root dry matter of rice seedlings were not different for seeds grown in different periods. Regarding the response of this same variable to sowing density, Salau et al. (2017), working with four populations of barley plants $\left(44,66,88\right.$, and 110 plant. $\left.\mathrm{m}^{-2}\right)$ in Pelotas, RS, found that shoot dry matter was not modified by an increase in plant. $\mathrm{m}^{-2}$; however, they found that root dry matter fit a quadratic equation with minimum value at the density of 70 plant. $\mathrm{m}^{-2}$.

The seedling emergence speed index for seeds from both cultivars was greater for seeds grown in period 1 (Table 1). However, for seedling emergence in sand, there was no significant effect from growing periods, densities, and interaction between the factors for either of the cultivars analyzed in the present study.

The results obtained show that delay in sowing of both cultivars caused reduction in seed quality. Among the meteorological elements, those of most prominence and that seem to explain the lower physiological performance of seeds as a result of later sowing were rainfall and air temperature, especially during the crop vegetative growth period (Figure 1). In that period, lower rainfall and higher temperatures favored accelerated vegetative development, which 
resulted in contraction of the cycle of plants sown/grown in period 2, reducing their growth. These morphophysiological changes may have limited yield capacity and distribution of photoassimilates of the plants, affecting the development and accumulation of reserves in the seeds and, consequently, their quality.

Temperatures rose to beyond $32{ }^{\circ} \mathrm{C}$ during the final phase of seed maturation of the plants grown in period 2. According to Marcos-Filho (2015), higher temperature, reaching values higher than $30^{\circ} \mathrm{C}$ during the seed development period, can cause severe losses in seed yield and quality. The same author affirms that these losses are related to the significant reduction in filling time and in the photosynthetic rate after flowering. In addition, Castro et al. (2012) report that in winter cereal crops, temperatures greater than or equal to $32{ }^{\circ} \mathrm{C}$ during one or more days in the maturation phase stop seed development and lead to early seed maturation. This situation may also have contributed to reduction in the vigor of seeds produced in period 2.

In this same context, high temperatures during maturation also lead to reduction in translocation of photoassimilates to the seeds. Under these conditions, maturation is "forced", producing low vigor seeds, because natural deposition of carbohydrates, lipids, and proteins is limited (Castro et al., 2012).

Another factor that may have contributed to improve the physiological performance of seeds produced by the IPR Afrodite e IPR Artemis cultivars in period 1 was the greater weight of these seeds (Figures 2A and 2B). According to Carvalho and Nakagawa (2012), seeds of greater weight usually have well-formed embryos with more reserves, and thus potentially have greater vigor.

Albrecht et al. (2008) report that the choice of the sowing date is the crop factor that by itself most affects plant development, crop yield, and seed quality. In this respect, Marcos-Filho (2015) affirms that the effect of the environment on seed development is mainly reflected in variations in the size, weight, and physiological quality of the seeds, which is confirmed by the results obtained in the present study.

The response of seed physiological potential in relation to the increase in seed sowing density varied considerably between the IPR Afrodite and IPR Artemis cultivars. According to Marcos-Filho (2015), the physiological response of seeds is based on the genotype, as a consequence of genetic and/or morphophysiological traits, which make them more or less susceptible to damage during the formation period or after physiological maturity of the seeds. However, the interaction between the genetic potential of the cultivar and crop management techniques can result in changes in the expression of yield components, yield, and seed quality (Silva et al., 2015).

Just as in the present study, variations in seed physiological quality as a result of modifications in the sowing density of the plants that produced them were also found by Salau et al. (2017), Barbieri et al. (2013), and Schuch et al. (2000b) working with barley, wheat, and black oat crops, respectively.

In general, increase in sowing density for both cultivars, though especially in the second growing period, resulted in little change or in reduction of the vigor of the seeds the cultivars produced. Greater competition among oat plants for resources from their environment as a result of the greater number of seeds per area may explain the results obtained in these cases. In this regard, the increase in sowing density in association with worse meteorological conditions during the cycle of plants grown in period 2 led to losses in the traits related to seed vigor.

This study shows that the potential for producing quality seeds can be optimized by growing plants in periods that favor plant growth and development through adequate choice of sowing time, a management practice characterized by the changes it effects in the relationships among the meteorological elements available to the crop throughout its cycle. According to Ramos et al. (2013), this strategy allows different phenological stages of the crop to occur at times in which the climate conditions are more favorable for the plant, which has a positive effect on production of quality seeds.

Furthermore, an increase in sowing density reduces the vigor of the seeds produced by the IPR Afrodite and IPR Artemis cultivars in the later growing period. Thus, combined use of the results of the various tests that evaluated seed vigor in the present study confirms the possibility of using 180 seed. $\mathrm{m}^{-2}$ in setting up the crop in period 1 , which would ensure production of high quality seeds and would allow reduction in the quantity of seeds used. 


\section{CONCLUSIONS}

The two sowing dates exhibit potential for production of oat seeds, resulting in seeds with germination that meets the standards for commercialization of seeds of the species.

The seeds produced by plants grown in the first plant growing period exhibit greater vigor than those produced by plants grown in the later growing period.

The increase in sowing density reduces the weight and vigor of seeds produced in the second growing period.

For the IPR Afrodite and IPR Artemis cultivars, the use of 180 seed. $\mathrm{m}^{-2}$ in the first growing period allows production of seeds with greater physiological potential.

\section{REFERENCES}

ABATI, J.; BRZEZINSKI, C.R.; FOLONI, J.S.S.; ZUCARELI, C.; BASSOI, M.C.; HENNING, F.A. Seedling emergence and yield performance of wheat cultivars depending on seed vigor and sowing density. Journal of Seed Science, v.39, n.1, p.1-8, 2017. http://www.scielo. br/scielo.php?script=sci_arttext\&pid=S2317-15372017000100058

ALBRECHT, L.P.; BRACCINI, A.L.; SCAPIM, C.A.;AGUIAR, C.G.; ÁVILA, M.R.; STÜLP, M. Qualidade fisiológica e sanitária das sementes sob semeadura antecipada da soja. Scientia Agraria, v.9, n.4, p.445-454, 2008. https://revistas.ufpr.br/agraria/article/view/12476/8645

ALMEIDA, M.L.; MUNDSTOCK, C.M. O afilhamento da aveia afetado pela qualidade da luz em plantas sob competição. Ciência Rural, v.31, n.3, p.393-400, 2001. http://www.scielo.br/scielo.php?script=sci_arttext\&pid=S0103-84782001000300005

ALMEIDA, M.L.; SANGOI, L.; ENDER, M.; WAMSER, A.F. Tillering does not interfere on white oat grain yield response to plant density. Scientia Agricola, v.60, n.2, p.253-258, 2003. http://www.scielo.br/scielo.php?script=sci_arttext\&pid=S0103-90162003000200008

BARBIERI, A.P.P.; MARTIN, T.N.; MERTZ, L.M.; NUNES, U.R.; CONCEIÇÃO, G.M. Redução populacional de trigo no rendimento e na qualidade fisiológica das sementes. Revista Ciência Agronômica, v.44, n.4, p.724-731, 2013. http://www.scielo.br/scielo. php?script=sci_arttext\&pid=S1806-66902013000400008

BORNHOFEN, E.; BENIN, G.; GALVAN, D.; FLORES, M.F. Épocas de semeadura e desempenho qualitativo de sementes de soja. Pesquisa Agropecuária Tropical, v.45, n.1, p.46-55, 2015. https://www.revistas.ufg.br/pat/article/view/29143

BRASIL. Ministério da Agricultura, Pecuária e Abastecimento. Regras para análise de sementes. Ministério da Agricultura, Pecuária e Abastecimento. Secretaria de Defesa Agropecuária. Brasília: MAPA/ACS, 2009. 395p. https://www.abrates.org.br/files/regras_ analise_de_sementes.pdf

CARON, B.O.; OLIVEIRA, D.M.; ELLI, E.F.; ELOY, E.; SCHWERZ, F.; SOUZA, V.Q. Elementos meteorológicos sobre características morfológicas e produtivas do milho em diferentes épocas de semeadura. Cientifica, v.45, n.2, p.105-114, 2017. http://cientifica. org.br/index.php/cientifica/article/view/910

CARVALHO, N.M.; NAKAGAWA, J. Sementes: ciência, tecnologia e produção. 5. ed. Jaboticabal: FUNEP, 2012. 590p.

CASTRO, G.S.A.; COSTA, C.H.M.; FERRARI-NETO, J. Ecofisiologia da aveia branca. Scientia Agraria Paranaensis, v.11, n.3, p.1-15, 2012. http://e-revista.unioeste.br/index.php/scientiaagraria/article/view/4808

COSTA, L.; ZUCARELI, C.; RIEDE, C.R. Parcelamento da adubação nitrogenada no desempenho produtivo de genótipos de trigo. Revista Ciência Agronômica, v.44, n.2, p.215-224, 2013. http://www.scielo.br/scielo.php?script=sci_ arttext\&pid=S1806-66902013000200002

FREITAS, M.C.M.; HAMAWAKI, O.T.; BUENO, M.R.; MARQUES, M.C. Época de semeadura e densidade populacional de linhagens de soja UFU de ciclo semitardio. Bioscience Journal, v.26, n.5, p. 698-708, 2010. http://www.seer.ufu.br/index.php/biosciencejournal/ article/view/7203

GOMES, G.D.R.; BENIN, G.; ROSINHA, R.C.; GALVAN, D.; PAGLIOSA, E.S.; PINNOW, C.; SILVA, C.L.; BECHE, E. Produção e qualidade fisiológica de sementes de soja em diferentes ambientes de cultivo. Semina: Ciências Agrárias, v.33, n.6, p.2593-2604, 2012. http:// www.uel.br/revistas//uel/index.php/semagrarias/article/view/8142/0 
MAGUIRE, J.D. Speed of germination-aid in selection and evaluation for seedling emergence and vigor. Crop Science, v.2, n.1, p.176177, 1962. https://acsess.onlinelibrary.wiley.com/doi/abs/10.2135/cropsci1962.0011183X000200020033x

MARCOS-FILHO, J. Fisiologia de sementes de plantas cultivadas. 2. ed. Londrina: ABRATES, 2015. 660p.

NAKAGAWA, J. Testes de vigor baseados no desempenho de plântulas. In: KRZYZANOWSKI, F.C.; VIEIRA, R.D.; FRANÇA-NETO, J.B. (ed.). Vigor de sementes: conceitos e testes. Londrina: ABRATES, 1999. p.2.1-2.24.

RAMOS, D.T.; ROQUE, M.W.; RAMOS, F.T.; SILVA, A.B.; PARO, H.; MATTE, W.D. Diferentes épocas de semeadura na produção de trigo de sequeiro em Mato Grosso. Global Science and Technology, v.6, n.3, p.45-56, 2013. https://rv.ifgoiano.edu.br/periodicos/index. php/gst/article/view/559

SALAU, G.M.; ARAÚJO, B.O.N.; DUBAL, I.T.P.; TROYJACK, C.; PIMENTEL, J.R.; MONTEIRO, M.A.; AISENBERG, G.R.; KOCH, R.; AUMONDE, T.Z.; PEDÓ, T. Crescimento de plantas e qualidade de sementes de cevada produzidas em baixas densidades populacionais. Tecnologia e Ciência Agropecuária, v.11, n.5, p.47-51, 2017. http://revistatca.pb.gov.br/edicoes/volume-11-2017/v-11-n-5dezembro-2017/08-crescimento-de-plantas-e-qualidade-de-sementes-cevada.pdf

SCHUCH, L.O.B.; NEDEL, J.L.; ASSIS, F.N.; MAIA, M.S. Vigor de sementes e análise de crescimento de aveia preta. Scientia Agricola, v.57, n.2, p.305-312, 2000a. http://www.scielo.br/scielo.php?script=sci_arttext\&pid=S0103-90162000000200018

SCHUCH, L.O.B.; NEDEL, J.L.; ASSIS, F.N.; MAIA, M.S. Vigor de sementes de populações de aveia preta: II. Desempenho e utilização de nitrogênio. Scientia Agricola, v.57, n.1, p.1-9, 2000b. http://www.scielo.br/scielo.php?script=sci_arttext\&pid=S010390162000000100020\&lng=pt\&tlng=pt

SILVA, A.C.; MORAIS, M.O.; SANTOS, J.L.; D’ARÊDE, L.O.; SILVA, P.B. Componentes de produção, produtividade e qualidade de sementes de feijão-caupi em Vitória da Conquista, Bahia. Revista Agroambiente, v.8, n.3, p.327-335, 2014. https://revista.ufrr.br/ agroambiente/article/view/1894

SILVA, J.A.G.; ARENHARDT, E.G.; KRÜGER, C.A.M.B.; LUCCHESE, O.A.; METZ, M.; MAROLLI, A. A expressão dos componentes de produtividade do trigo pela classe tecnológica e aproveitamento do nitrogênio. Revista Brasileira de Engenharia Agrícola e Ambiental, v.19, n.1, p.27-33, 2015. http://www.scielo.br/scielo.php?script=sci_arttext\&pid=S1415-43662015000100027

SILVA, R.R.; BENIN, G.; SILVA, G.O.; MARCHIORO, V.S.; ALMEIDA, J.L.; MATEI, G. Adaptabilidade e estabilidade de cultivares de trigo em diferentes épocas de semeadura, no Paraná. Pesquisa Agropecuária Brasileira, v.46, n.11, p.1439-1447, 2011. http://www. scielo.br/scielo.php?script=sci_arttext\&pid=S0100-204X2011001100004\&lng=pt\&tlng=pt

TAFERNABERRI-JÚNIOR, V.; DALL'AGNOL, M.; MONTARDO, D.P.; PEREIRA, E.A.; PERES, E.R.; LEÃO, M.L. Avaliação agronômica de linhagens de aveia branca em duas regiões fisiográficas do Rio Grande do Sul. Revista Brasileira de Zootecnia, v.41, n.1, p.41-51, 2012. http://www.scielo.br/scielo.php?pid=S1516-35982012000100007\&script=sci_abstract\&tlng=pt

TAVARES, L.C.V.; FOLONI, J.S.S.; BASSOI, M.C.; PRETE, C.E.C. Genótipos de trigo em diferentes densidades de semeadura. Pesquisa Agropecuária Tropical,v.44,n.2,p.166-174,2014.http://www.scielo.br/scielo.php?script=sci_arttext\&pid=S1983-40632014000200010

TOLEDO, M.Z.; COIMBRA, R.A.; NAKAGAWA, J. Qualidade fisiológica e armazenamento de sementes de milheto em função da época de semeadura. Bioscience Journal, v.25, n.3, p.16-23, 2009. http://www.seer.ufu.br/index.php/biosciencejournal/article/view/6904

VENSKE, E.; SCHAEDLER, C.E.; BAHRY, C.A.; CAMARGO, T.O.; ZIMMER, P.D. Fatores abióticos sobre o efeito de herbicidas na qualidade fisiológica de sementes de arroz. Revista Ciência Agronômica, v.46, n.4, p.818-825, 2015. http://ccarevista.ufc.br/seer/index.php/ ccarevista/article/view/3880

VENSKE, E.; SCHAEDLER, C.E.; RITTER, R.; FIN, S.S.; BAHRY, C.A.; AVILA, L.A.; ZIMMER, P.D. Seletividade de herbicidas sobre arroz irrigado em resposta à época de semeadura e redução da luminosidade em fases do desenvolvimento. Revista Ceres, v.63, n.2, p.165-173, 2016. http://www.scielo.br/scielo.php?script=sci_arttext\&pid=S0034-737X2016000200165\&lng=pt\&tlng=pt

ZAGONEL, J.; VENANCIO, W.S.; KUNZ, R.P. Efeito de regulador de crescimento na cultura do trigo submetido a diferentes doses de nitrogênio e densidades de plantas. Planta Daninha, v.20, n.3, p.471-476, 2002. http://www.scielo.br/scielo.php?script=sci_ arttext\&pid=S0100-83582002000300019\&lng=pt\&tlng=pt 